\title{
Are workplaces with many women in management run differently?
}

\section{Eduardo Melero*}

Department of Business Administration, Universidad Carlos III de Madrid, Spain

\begin{tabular}{ll}
\hline A B S T R A C T \\
$\begin{array}{l}\text { Are workplaces with a high percentage of women in management run differently? This paper uses data from } \\
\text { the British } 1998 \text { Workplace Employee Relations Survey (WERS98) to analyze empirically the relationship } \\
\text { between the percentage of female workplace managers and people management practices. The results show } \\
\text { that workplace management teams with a higher proportion of women monitor employee feedback and } \\
\text { development more intensely. Such teams also tend to promote more interpersonal channels of } \\
\text { communication and more employee participation in decision making, although the evidence is weaker for } \\
\text { these last two practices. Overall, the findings suggest that the concept of good workplace management } \\
\text { practices converges on female leadership styles when the percentage of female managers increases. }\end{array}$ \\
$\begin{array}{l}\text { Keywords: } \\
\text { Women in management }\end{array}$ \\
$\begin{array}{l}\text { People-management practices } \\
\text { Managerial behavior }\end{array}$
\end{tabular}

\section{Introduction}

The last three decades witness a steady increase in the proportion of women in the management of organizations in all developed countries. In the United States, for example, the percentage of female managers has grown from $18 \%$ in 1972 to about $45 \%$ in 2002 . Analogously, figures for the United Kingdom doubled from 20 to $40 \%$ within a similar period (United States Bureau of Labor Statistics, 2007; United Kingdom Statistics Authority, 2007). This growth in the number of female managers stimulates the debate about its potential consequences for management. Extensive empirical research addresses the extent to which men and women diverge in their leadership styles. The meta analytical review by Eagly and Johannesen Schmidt (2001) shows significant differences between men and women in their tendency to lead democratically and in their individualized consideration of employees.

Despite these gender differences in individual leadership styles, little is known about whether workplaces with a higher presence of women in management are run differently. The present study fills this gap in the literature by examining to what extent the percentage of female managers in a workplace is associated with the type of management practices adopted. This question is particularly relevant since patterns of management practices are probably more important for long term workplace performance than individual managers' specific styles. Employee participation in decision making, for example, is especially important to boost an organization's ability to innovate (Michie and Sheehan, 1999). Nonetheless, hiring managers with a more participative style is ineffectual if they are not able to establish proper channels for employee participation.

\footnotetext{
* Corresponding author. Universidad Carlos III de Madrid Department of Business Administration Calle Madrid 12628903 Getafe (Madrid)Spain. Tel.: +34 916248918 E-mail address: eduardo.melero@uc3m.es.
}

The effect of gender differences in (individual) leadership styles on (collective) workplace management practices is not obvious. Top executives typically serve as leadership models in their organiza tions, largely influencing culture and management actions (Kerfoot and Knights, 1993). Hence, as women account for a smaller per centage of senior management (Catalyst, 2005), their ability to influence management practices may be modest. Nevertheless, the influence of members belonging to minorities increases when their proportion in working groups grows, since their colleagues are less likely to perceive them as tokens (Kanter, 1977). Accordingly, increases in the percentage of female managers even if more intense at low and middle levels will contribute to the implemen tation of the practices that women tend to prefer. This study departs from the observed gender differences in leadership styles (Eagly and Johannesen Schmidt, 2001) and draws on the literature on group demography (Blau, 1977; Kanter, 1977) to elucidate the relationship between the percentage of female managers in the workplace and people management practices. The resulting hypotheses state that workplace management practices reflect women's preference for interpersonal interaction, democratic decision making and individ ualized consideration of employees when the percentage of female managers is high.

To test these hypotheses, this study uses data from the 1998 Workplace Employment Relations Survey (WERS98). A nationwide representative survey of British workplaces, the WERS98 includes a wide range of information on management practices, and workforce and workplace characteristics. This type of survey data enables the researcher to perform multivariate analyses taking account of many relevant organizational issues. In particular, the study exploits the WERS98 data to analyze the relationship between the per centage of female workplace managers and people management practices while keeping constant important workplace and work force features. 


\section{Theory and hypothesis}

Extensive theoretical and empirical literature addresses gender differences in leadership styles (Butterfield and Grinnell, 1999). Although the relevance of these differences depends largely on their effect on collectively decided management practices, there is little research on this latter topic. An exception is Thomas (1991), which analyzes the effects of changes in the gender composition of decision making groups in the political arena. Her results reveal that higher proportions of women in legislatures are associated with the introduction of a larger number of priority bills dealing with issues of women, children and families. However, no theoretical or empirical study to date deals with the type of practices that workplace management teams with a higher percentages of women managers promote.

A key issue modulating the link between the percentage of female workplace managers and the type of practices adopted is the ability of these women to affect decisions. Women frequently lack the influence required to promote the implementation of their preferred practices (Ridgeway and Berger, 1986). However, research on group demog raphy suggests that the influence of women, who are typically a minority within the administration team, increases with their relative presence in management (Kanter, 1977; Izraeli, 1983; Carli, 2001). In general, the status of members of a minority group tends to improve as the relative size of that group increases and membership of it becomes less of a distinguishing factor (Berger et al., 1977). Furthermore, prejudices against female managers are less intense when their proportion is higher and their colleagues are less likely to perceive them as tokens. Tokenism is a phenomenon that leads to the informal isolation of minority members who, in turn, respond by keeping a low profile (Kanter, 1977); this dynamic impairs the ability of token women managers to exert influence on decisions when they are a minority within the management team. Conversely, as the percentage of female managers increases and the group becomes more balanced, women stop being atypical members of the team. The result is that discriminatory actions against them decline, they are able to behave in a less restrained way and, therefore, have more influence on group decision making.

If women have preferences for specific leadership styles, they will tend to support management practices that are consistent with them. Consequently, as the percentage of female managers in a workplace increases, people management practices will reflect women's pre ferences more intensely. This outcome is due, first, to a relatively larger group of managers supporting a particular type of practices and, second, to the greater influence that this group of managers enjoys as its proportion increases. The following hypotheses specify how management practices are expected to vary when the percentage of women in the management team increases, taking as reference the dimensions of leadership styles in which male and female managers differ.

\subsection{Task and interpersonal orientation}

The debate about specific aspects of gender differences in leadership styles typically involves two dimensions (Bales, 1950): task orientation and interpersonal orientation. Task oriented man agers let their employees know what the organization expects from them in precise terms, usually in the form of a comprehensive description of tasks and goals. On the other hand, interpersonally oriented managers build their leadership on keeping the morale of their subordinates high and showing concern about their welfare at work. According to gender roles, female managers should be more prone to lead with an interpersonal orientation, while male managers should be more likely to apply a task oriented style (Powell and Graves, 2003; Eagly and Johnson, 1990). The meta analytical study by Eagly and Johnson (1990) reports that women tend to lead in a more interpersonal way than men in laboratory and assessment studies. However, they do not find significant differences between real managers of both genders in either interpersonal or task orientation.

To the extent that female workplace managers prefer to lead in a less task oriented and more interpersonal way, they will tend to support practices that are consistent with these leadership styles. They will lobby for a flexible definition of subordinates' tasks, they will seek to promote more frequent interactions between managers and subordinates, and they will try to establish less formal channels of communication. Such attempts to shape people management prac tices will be more successful when the percentage of women in management is higher and female managers exert greater influence.

Hypothesis 1. (Task orientation): Workplace management teams with higher percentages of women define employees' tasks in a more flexible way.

Hypothesis 2. (Interpersonal orientation): Workplace management teams with higher percentages of women interact more frequently with subordinates and rely less on formal channels of communication.

\subsection{Democracy in decision making}

Male and female leaders can also differ in the extent to which they behave autocratically or encourage subordinates to participate in decision making. Participative (or democratic) managers discuss decisions with their subordinates and try to build a consensus with them in order to obtain better implementation (Vroom and Yetton, 1973). Conversely, autocratic leaders tend to adopt a directive style, defining actions by themselves before communicating them to their subordinates. This latter leadership style involves some of the features that typically characterize the masculine role, such as dominance and control. Conversely, the democratic style is more consistent with the features of the feminine role, which encourages the participation of others in decision making (Eagly and Johnson, 1990). The evidence compiled by Eagly and Johnson (1990) suggests that female managers tend to lead in a more participative way, while their male counter parts are more directive and autocratic.

To the extent that women managers prefer to decide in a more participative way, they will also support more democratic practices with respect to workplace level decision making. This support for employee participation in workplace decisions will only be effective when the percentage of female managers is high and they can exercise relevant influence on the management team.

Hypothesis 3. (Democracy versus autocracy): Workplace manage ment teams with higher percentages of women consult more intensively with employees before making decisions.

\subsection{Individualized consideration}

Another dimension in which leadership styles differ is the degree of Transformational Leadership. The concept of Transformational Leader ship, introduced by Burns (1978) is an important reference in contemporaneous analyses of leadership styles (Bass and Riggio, 2006). A transformational leader establishes high behavioral standards by: (1) exerting an idealized influence that makes him/her a role model for subordinates, (2) being their constant source of inspiration, (3) stimulating them to be creative and innovative, and (4) displaying an individualized consideration of them through mentoring, coaching and careful monitoring of their needs. Leadership scholars usually describe this style as opposed to the transactional style (which associates manager subordinate transactions with exchange relationships) and the laissez faire style (a simple failure to fulfill the leadership role). As Eagly and Johannesen Schmidt (2001) state, most features of the transformational style do not relate directly to either gender role. 
Nonetheless, the more intense social behavior of the feminine role places women in a better position to offer individualized consideration to their subordinates. Eagly and Johannesen Schmidt (2001), Carless (1998) and, to a lesser degree, Maher (1997), provide empirical evi dence supporting this view.

To the extent that female managers tend to offer more individu alized consideration to employees, they will support management practices that help to harness it. Thus, they will promote mentoring activities and structures that stimulate employee feedback. Work places with higher percentage of women managers will display higher female influence in the definition of management practices and, therefore, they will show stronger implementation of mentoring activities and employee feedback structures.

Hypothesis 4. (Individualized consideration). Workplace manage ment teams with higher percentages of women place a higher emphasis on obtaining feedback from employees and carry out more mentoring activities.

\section{Methods}

\subsection{Data and sampling procedures: the WERS98}

Information about workplace management practices is needed to test the proposed hypotheses. The data from the WERS98 survey (Department of Trade and Industry, 1999) is most suitable for such analysis. The WERS98 is a national survey conducted by the National Centre for Social Research for the Department of Trade and Industry of the UK central government. The survey draws its sample from the Inter Departmental Business Register and covers all workplaces across Britain with more than 10 employees, excluding agriculture, forestry and fishing, and coal mining. From a population of some 341,411 eligible workplaces, the survey extracts a target of 2729 units through stratified random sampling. The final sample includes 2193 workplaces, with a response rate of $80.4 \%$ (for more details, see the technical report by Airey et al., 1999).

The WERS98 collects information about employment relations from several sources, namely: (1) management (Management Questionnaire), (2) a representative of workers, and (3) for 1759 workplaces, a random sample of up to 25 employees (Employee Questionnaire). The survey also gathers information on workforce characteristics from each workplace (Employee Profile Question naire). The senior manager dealing with personnel, staff or employee relations answers the Management Questionnaire, which includes most of the relevant information about people management prac tices. The Employee Questionnaire and the Employee Profile Ques tionnaire provide additional information about average age, education and occupation of employees as well as their view of people management practices.

Women hold an average of about $30 \%$ of management positions in the workplaces surveyed by the WERS98. The figures from the Workplace Change subsection of the Management Questionnaire reflect the motivation for this article: more than $48 \%$ of workplaces report an increase in the proportion of women in management during the period 1993 1998, whereas only 4\% report a decrease. At the same time, a majority of workplaces report increases in the importance of employee relations matters (70\%, against $2 \%$ that report a decrease) and increases in labor productivity (79\%, against $4 \%$ that report a decrease).

\subsection{Analytical approach}

The central methodological approach of this research is a multivar iate regression analysis of the relationship between the implementa tion of several people management practices and the percentage of females in workplace management. The wide scope of the WERS98 makes it possible to perform an analysis of this type while controlling for a large set of workplace and workforce characteristics.

The information about the implementation of different practices dependent variables of the regression analysis stems from several key questions posed in the interview that produced the Management Questionnaire data. An important issue that arises in the analysis of this type of data is the correlation between the different practices. Even if the practices are conceptually independent from each other, the existence of synergies between some of them could make their joint execution particularly profitable. Effective implementation of employee participation initiatives, for example, may require more interpersonal communication. In that case, managers would choose to introduce these practices in bundles, as part of a general policy, rather than in isolation (Milgrom and Roberts, 1995). As a result, it would become necessary to aggregate practices before analyzing their relationship to the composition of the management team.

Consequently, a first step in this article's analytical strategy involves assessing the factorability of people management practices into a smaller set of policy trends. Several methods serve this purpose. First, the simplest and most obvious of them is the examination of the correlation matrix. Second, Bartlett's (1950) test of sphericity is a more rigorous test of the null hypothesis that the correlation matrix comes from a population of variables that are independent. However, the Bartlett test is more useful for ruling out data sets that are inappropriate for factor analysis than for reliably identifying sets that are appropriate (Knapp and Swoyer, 1967). Finally, the Kaiser Meyer Olkin measure of sampling adequacy (MSA) provides a measure of the extent to which the variables belong together and are thus appropriate for factor analysis. The MSA ranges from 0 to 1 and is generally viewed as the most accurate of the available methods (Stewart, 1981). Kaiser and Rice (1974) provide a calibration of the MSA based on extensive experience. They label any value of the MSA below 0.6 as "miserable", indicating that the data does not lend itself to factor analysis. On the contrary, they rate values of MSA above 0.8 as "meritorious", which suggests the data is appropriate for factor analysis.

Once the analysis of the structure of the management practices data set yields a recommendation, the next step is regression analysis either for each original dependent variable or for each factor. If it is not possible to bundle the practices into policy trends, Ordered Probit Regression is the method that best accommodates the Likert scale format of the original dependent variables. If it is possible to summarize the practices into a few factors, a maximum likelihood factor analysis with varimax rotation precedes regression analysis. In this second case, the scores resulting from factor analysis reflect the degree of implementation of each policy trend in each workplace and they can serve as dependent variables of the study. Since factor scores are on a continuous scale, OLS regression is the suitable method for their analysis. The coefficients resulting from the regression analysis make it possible to determine the direction and significance of the effect of the percentage of female managers on management practices, while controlling for workplace and workforce character istics. According to conventions, estimated effects with $P$ value lower than 0.05 are significantly different than zero. A P value between 0.05 and 0.10 can be interpreted as weak evidence of the existence of a significant effect (Aguinis et al., 2010).

In order to check the robustness of the results and assess potential method related biases, the study repeats part of the analysis using employees' written reports from the Employee Questionnaire as dependent variables. As in the case of the questions from the Management Questionnaire, assessing the factorability of the raw dependent variables is a required step prior to the regression analysis.

\subsection{Dependent variables}

Some of the specific questions on workplace relationships from the WERS98 Management Survey are appropriate to measure the type of 
workplace level management practices that are the subject of this article. Table 1 provides a summary of them as well as their correlation matrix.

First, to approach flexibility in the definition of tasks, this study uses the question on the extent to which "managers ask employees to help them in ways not specified in their job description". A high value of the variable that measures answers to this question implies that the management team makes a flexible interpretation of formal job descriptions. Second, to deal with the intensity of personal interac tions between managers and subordinates, two questions are particularly useful: the degree to which "management prefers to consult directly with employees instead of their representatives" and "whether managers are considered as instruments for workers to make direct suggestions". Positive answers to these two questions imply more intense and less formal interactions between managers and subordinates. Third, two survey questions are especially appro priate to measure the degree of democracy in decision making in the workplace: whether "management discusses possible workplace changes with workers before introducing them" and whether "most decisions are made without consulting employees". Although the variables resulting from the answers to these two questions are strongly related, their correlation coefficient is still far from -1 and, therefore, each of them provides some independent information about the degree of employee participation in managerial decision making. Finally, the fourth hypothesis covers the degree of concern about employee feedback and the focus on subordinate mentoring. Two survey questions refer to them: "the proportion of time in informative briefing meetings given to employees to offer views and pose questions" and the "use of performance appraisals to give feedback to employees, discuss their career moves and set their personal objectives".
According to Table 1, the pair wise correlations between the different practices are relatively small (most coefficients are below 0.1 ), but statistically significant in many cases. Therefore, the existence of potential complementarities is an issue that deserves further attention. Although the Bartlett's test rejects the null hypothesis of no correlation among the variables of interest, the Keiser Meyer Olkin measure suggests that the existing correspon dences are rather weak. The computed magnitude of the MSA is 0.55. This value falls within the "miserable" category in Kaiser and Rice's (1974) calibration of factorability, which suggests that the data on management practices is inappropriate for factor analysis. Intuitively, this result means that each of the selected questions provides substantial information on some independent dimension of manage ment practices and therefore, each of them merits separate analysis.

\subsection{Explanatory variables}

Table 2 summarizes the explanatory variables of the analysis. The most relevant one for this research is the proportion of workplace managers who are women, that is, the percentage of female managers. Several factors can both increase the proportion of in women in management and create changes in people management practices. Such factors include workforce and workplace character istics. The WERS98 includes information on both aspects, so that it is possible to control for them in a multivariate analysis. The percentage of women in the workplace's non managerial labor force is a particularly important control variable. The reason is that higher percentages of female managers could result from higher percentages of female non managers, and organizations with relatively more women in the non managerial workforce may require special types of

Table 1

Management practices and their correlation matrix. Sample correlation coefficients (Pearson) with p-values in parentheses.

\begin{tabular}{|c|c|c|c|c|c|c|}
\hline \multicolumn{3}{|l|}{ Variable description } & Mean (standard deviation) & \multicolumn{3}{|l|}{ Measurement } \\
\hline \multicolumn{3}{|c|}{$\begin{array}{l}\text { Whether managers ask employees to help them in ways not specified in } \\
\text { their job description }\end{array}$} & $3.3(1.1)$ & \multicolumn{3}{|c|}{$\begin{array}{l}\text { Discrete scale of agreement } 1 \text { to } 5 \text { : } \\
\text { 1: strongly disagree } \\
\text { 2: disagree } \\
\text { 3: not agree nor disagree } \\
\text { 4: agree } \\
\text { 5: strongly agree }\end{array}$} \\
\hline \multicolumn{3}{|c|}{$\begin{array}{l}\text { Whether managers rather consult directly with employees than with their } \\
\text { representatives }\end{array}$} & $3.7(1.1)$ & \multicolumn{3}{|c|}{ Discrete scale of agreement 1 to 5} \\
\hline \multicolumn{3}{|c|}{$\begin{array}{l}\text { Whether managers are considered a channel through which employees can } \\
\text { make suggestions }\end{array}$} & $0.25(0.43)$ & \multicolumn{3}{|l|}{ No $=0 /$ Yes $=1$} \\
\hline \multirow{2}{*}{\multicolumn{3}{|c|}{$\begin{array}{l}\text { Whether managers discuss with workers any change before introducing it } \\
\text { Whether most decisions at workplace are made without discussing them } \\
\text { with employees }\end{array}$}} & $3.7(1.0)$ & \multicolumn{3}{|c|}{$\begin{array}{l}\text { Discrete scale of agreement } 1 \text { to } 5 \\
\text { Discrete scale of agreement } 1 \text { to } 5\end{array}$} \\
\hline & & & $2.3(1.0)$ & Discrete scale of & eement 1 to 5 & \\
\hline \multicolumn{3}{|c|}{$\begin{array}{l}\text { Proportion of time in informative briefing meetings given to employees to } \\
\text { offer views and pose questions }\end{array}$} & $2.0(1.1)$ & \multicolumn{3}{|c|}{$\begin{array}{l}\text { Discrete scale } 1 \text { to } 4 \\
\text { 1:Either no briefing or workers are not allowed to participate } \\
\text { 2: less than } 10 \% \text { of time } \\
\text { 3: } 10-24 \% \\
4: 25 \% \text { or more }\end{array}$} \\
\hline \multicolumn{3}{|c|}{$\begin{array}{l}\text { Whether the firm uses performance appraisals to give feedback to employees, } \\
\text { discuss their career moves and set their personal objectives }\end{array}$} & $0.76(0.43)$ & \multicolumn{3}{|c|}{ No $=0 /$ Yes $=1$} \\
\hline & $\begin{array}{l}\text { Ask help in } \\
\text { unspecified ways }\end{array}$ & $\begin{array}{l}\text { Talk directly } \\
\text { to employees }\end{array}$ & $\begin{array}{l}\text { Managers as channel } \\
\text { for suggestions }\end{array}$ & Discuss changes & $\begin{array}{l}\text { Not consult } \\
\text { most decisions }\end{array}$ & Time to offer views \\
\hline Talk directly to employees & $\begin{array}{l}0.02 \\
(0.34)\end{array}$ & & & & & \\
\hline Managers as channel for suggestions & $\begin{array}{l}0.07 \\
(0.01)\end{array}$ & $\begin{array}{l}0.16 \\
(0.00)\end{array}$ & & & & \\
\hline Discuss changes & $\begin{array}{l}0.03 \\
(0.18)\end{array}$ & $\begin{array}{l}0.01 \\
(0.61)\end{array}$ & $\begin{array}{c}0.01 \\
(0.75)\end{array}$ & & & \\
\hline Not consult most decisions & $\begin{array}{c}0.02 \\
(0.51)\end{array}$ & $\begin{array}{c}0.09 \\
(0.00)\end{array}$ & $\begin{array}{c}0.04 \\
(0.11)\end{array}$ & $\begin{array}{c}0.47 \\
(0.00)\end{array}$ & & \\
\hline Time to offer views & $\begin{array}{c}0.09 \\
(0.00)\end{array}$ & $\begin{array}{c}0.01 \\
(0.70)\end{array}$ & $\begin{array}{c}0.03 \\
(0.23)\end{array}$ & $\begin{array}{c}0.12 \\
(0.00)\end{array}$ & $\begin{array}{c}0.22 \\
(0.00)\end{array}$ & \\
\hline Mentoring activities & $\begin{array}{c}0.12 \\
(0.00)\end{array}$ & $\begin{array}{c}0.03 \\
(0.26)\end{array}$ & $\begin{array}{c}0.13 \\
(0.00)\end{array}$ & $\begin{array}{c}0.08 \\
(0.02)\end{array}$ & $\begin{array}{c}0.15 \\
(0.00)\end{array}$ & $\begin{array}{c}0.16 \\
(0.00)\end{array}$ \\
\hline
\end{tabular}


Table 2

Explanatory variables.

\begin{tabular}{|c|c|c|}
\hline Variable description & $\begin{array}{l}\text { Mean (standard } \\
\text { deviation) }\end{array}$ & Measurement \\
\hline \multicolumn{3}{|l|}{ Key explanatory variables } \\
\hline Percentage of managers who are women & $0.32(0.31)$ & $\begin{array}{l}\text { Continuous } \\
\text { variable }\end{array}$ \\
\hline $\begin{array}{l}\text { Percentage of total number of employees } \\
\text { who are women }\end{array}$ & $0.50(0.29)$ & $\begin{array}{l}\text { Continuous } \\
\text { variable }\end{array}$ \\
\hline $\begin{array}{l}\text { Whether the manager responding to the } \\
\text { survey questions is a women }\end{array}$ & $0.42(0.49)$ & $\mathrm{No}=0 / \mathrm{Yes}=1$ \\
\hline \multicolumn{3}{|l|}{ Characteristics of the labor force } \\
\hline Average age of employees at the workplace & $39.0(5.8)$ & $\begin{array}{l}\text { Continuous } \\
\text { variable }\end{array}$ \\
\hline $\begin{array}{l}\text { Average years of education of employees } \\
\text { at the workplace (based on educational } \\
\text { qualifications) }\end{array}$ & $10.7(2.3)$ & $\begin{array}{l}\text { Continuous } \\
\text { variable }\end{array}$ \\
\hline $\begin{array}{l}\text { Proportion of total number of employees } \\
\text { who are: }\end{array}$ & & $\begin{array}{l}\text { Continuous } \\
\text { variable }\end{array}$ \\
\hline • Professional workers & $0.15(0.24)$ & \\
\hline • Technical workers & $0.09(0.17)$ & \\
\hline - Clerical or secretarial workers & $0.20(0.25)$ & \\
\hline - Skilled manual workers & $0.11(0.21)$ & \\
\hline - Personal service workers and operators & $0.20(0.30)$ & \\
\hline - Workers in sales occupations & $0.11(0.25)$ & \\
\hline - Unskilled manual workers & $0.13(0.23)$ & \\
\hline \multicolumn{3}{|l|}{ Workplace characteristics } \\
\hline $\begin{array}{l}\text { Total number of employees at } \\
\text { the workplace }\end{array}$ & $288.7(847.3)$ & $\begin{array}{l}\text { Continuous } \\
\text { variable }\end{array}$ \\
\hline $\begin{array}{l}\text { Whether the interviewed workplace } \\
\text { is an independent organization }\end{array}$ & $0.20(0.40)$ & $\mathrm{No}=0 / \mathrm{Yes}=1$ \\
\hline $\begin{array}{l}\text { Whether the organization is mostly } \\
\text { owned by foreign capital }\end{array}$ & $0.10(0.31)$ & $\mathrm{No}=0 / \mathrm{Yes}=1$ \\
\hline $\begin{array}{l}\text { Whether the firm is a public sector } \\
\text { company }\end{array}$ & $0.31(0.46)$ & $\mathrm{No}=0 / \mathrm{Yes}=1$ \\
\hline Years of longevity of the workplace & $35.6(48.3)$ & $\begin{array}{l}\text { Continuous } \\
\text { variable }\end{array}$ \\
\hline $\begin{array}{l}\text { SIC } 1992 \text { Code of main activity of } \\
\text { the workplace }\end{array}$ & & 12 Dummies 0/1 \\
\hline $\begin{array}{l}\text { Any type of union or staff association } \\
\text { at workplace }\end{array}$ & $0.66(0.47)$ & $\mathrm{No}=0 / \mathrm{Yes}=1$ \\
\hline
\end{tabular}

people management practices. It is also important to control for the gender of the respondent manager, which may affect his or her view of relationships in the workplace. Therefore, respondent manager gender is also present in the analysis.

Other characteristics of the workplace labor force including its age, education and distribution of occupations are also relevant control variables that can affect the type of practices in place. This study uses the personal data from the Employee Questionnaire to estimate the employees' average age and years of education in each workplace. Drawing on information from the Employee Profile Questionnaire, the analysis also incorporates a set of variables accounting for the proportion of employees in each of 7 different occupations.

The analysis also considers workplace characteristics that can affect people management practices. First, a control variable measur ing the total number of employees in the workplace accounts for its size. Second, a set of 12 dummy variables associated with the 1992 Standard Industrial Classification Code captures the industrial sector in which the workplace operates. Third, a set of three dummy variables account for workplace managers' autonomy: whether foreign shareholders own most of the capital of the organization to which the workplace belongs, whether it operates for the public sector, and whether the workplace is an independent organization. Fourth, "the number of years that the workplace has been operating" controls for its longevity. This last variable is present in the analysis because older workplaces may tend to apply more traditional management methods. Finally, a binary variable accounts for the presence of any type of union or similar workers' association that could influence people management practices.

\section{Results}

The dependent variables of interest take the form of discrete scales in the survey. Ordered Probit Regression is the most suitable method for analyzing their relationship to the relevant independent variables as it avoids the assumption of equal space between categories (see Wooldridge, 2002).

Table 3 shows the relevant results of the different Ordered Probit Regression models estimated for each management practice. The first row shows the effect of the percentage of women in the workplace's management on the degree of implementation of each practice. For each dependent variable, Table 3 presents the results from two specifications: a first one that controls for all the explanatory variables described above except the percentage of female non managers and the gender of the respondent, and a second one that also includes those two explanatory variables. Although the WERS98 includes a sample of 2193 workplaces, the final number of observations available for each analysis varies between 1547 and 1589, depending on the existence of valid data for all the relevant variables.

The first two columns of Table 3 report results that do not support Hypothesis 1 on task orientation. The effect of a higher percentage of female managers on the degree to which "managers ask employees to help them in ways not specified in their job description" is negative in both specifications. The estimated effect ceases to be statistically significant when the specification takes into account the percentage of female non managers and the gender of the respondent manager. These last two variables correlate strongly with the percentage of female managers (correlation coefficients are 0.60 and 0.41 , respec tively). Hence, the results from the second column suggest that the significant negative impact of the percentage of female managers from the first specification partly reflects the effect of a higher percentage of female non managers.

Columns (3) to (6) report the results for the two dependent variables that capture interpersonal communication practices: the extent to which "managers rather consult directly with employees than with representatives" (columns (3) and (4)) and the consider ation of "managers as channels for suggestions" (columns (5) and (6)). The effect of the percentage of women managers is positive for both practices, but it is never statistically significant for the second one. As for the practice of consulting directly with employees, the effect is significant at $10 \%$ when controlling for the percentage of female non managers. Therefore, these results provide weak support for Hypothesis 2, which proposes that interpersonal interactions between managers and subordinates tend to be more intense and less formal in organizations with more female managers.

Results from Table 3 also offer weak support for Hypothesis 3, which states that workplaces with higher percentages of female managers are more participative. As columns (7) to (10) indicate, the proportion of female managers affects the degree of democracy in decision making whether "managers discuss changes with emplo yees" and whether "managers take most decisions without discussing them with employees" in the direction that Hypothesis 3 predicts (positive and negative, respectively). However, when controlling for the percentage of female non managers, the effect of female managers ceases to be significant for the question restricted to the discussion of changes and is significant at only $10 \%$ for the general question on consulting most decisions.

Interestingly, discussing changes with workers is more likely at workplaces with more female non managers even though the latter variable has no significant effect on the general rate of consultation of most decisions. These findings may suggest that, in comparison with their male colleagues, women non managerial workers are especially interested in discussing decisions that imply changes in the status quo.

Hypothesis 4 receives the strongest support from the results of this study. As the last four columns of Table 3 show, the percentage of 
Women in management and people-management practices. Ordered Probit Estimates with standard errors in parentheses.

\begin{tabular}{|c|c|c|c|c|c|c|c|c|c|c|c|c|c|c|}
\hline & \multirow{2}{*}{\multicolumn{2}{|c|}{$\begin{array}{l}\text { Task orientation } \\
\text { Ask help in } \\
\text { unspecified } \\
\text { ways }\end{array}$}} & \multicolumn{4}{|c|}{ Interpersonal orientation } & \multicolumn{4}{|c|}{ Participation in decision-making } & \multicolumn{4}{|c|}{ Individualized consideration } \\
\hline & & & \multicolumn{2}{|c|}{$\begin{array}{l}\text { Talk directly } \\
\text { to employees }\end{array}$} & \multicolumn{2}{|c|}{$\begin{array}{l}\text { Managers as } \\
\text { channels for } \\
\text { suggestions }\end{array}$} & \multicolumn{2}{|c|}{ Discuss changes } & \multicolumn{2}{|c|}{$\begin{array}{l}\text { Not consult } \\
\text { most decisions }\end{array}$} & \multicolumn{2}{|c|}{$\begin{array}{l}\text { Time to offer } \\
\text { views }\end{array}$} & \multicolumn{2}{|l|}{$\begin{array}{l}\text { Mentoring } \\
\text { activities }\end{array}$} \\
\hline & (1) & $(2)$ & (3) & (4) & (5) & $(6)$ & (7) & $(8)$ & (9) & $(10)$ & (11) & $(12)$ & (13) & (14) \\
\hline $\begin{array}{l}\text { Percentage of } \\
\text { female managers }\end{array}$ & $\begin{array}{l}0.218^{* *} \\
(0.109)\end{array}$ & $\begin{array}{r}0.133 \\
(0.125)\end{array}$ & $\begin{array}{l}0.223^{* *} \\
(0.110)\end{array}$ & $\begin{array}{l}0.224^{*} \\
(0.125)\end{array}$ & $\begin{array}{l}0.192 \\
(0.157)\end{array}$ & $\begin{array}{l}0.242 \\
(0.181)\end{array}$ & $\begin{array}{l}0.207^{*} \\
(0.112)\end{array}$ & $\begin{array}{l}0.122 \\
(0.128)\end{array}$ & $\begin{array}{l}0.289^{* *} \\
(0.112)\end{array}$ & $\begin{array}{c}0.239^{*} \\
(0.128)\end{array}$ & $\begin{array}{l}0.283^{* *} \\
(0.115)\end{array}$ & $\begin{array}{l}0.391^{* *} \\
(0.131)\end{array}$ & $\begin{array}{l}0.416^{* *} \\
(0.151)\end{array}$ & $\begin{array}{l}0.355^{* *} \\
(0.172)\end{array}$ \\
\hline $\begin{array}{l}\text { Percentage of } \\
\text { female non- } \\
\text { managers }\end{array}$ & & $\begin{array}{r}0.211 \\
(0.158)\end{array}$ & & $\begin{array}{l}0.167 \\
(0.159)\end{array}$ & & $\begin{array}{c}0.423^{*} \\
(0.222)\end{array}$ & & $\begin{array}{l}0.331^{* *} \\
(0.161)\end{array}$ & & $\begin{array}{r}0.208 \\
(0.160)\end{array}$ & & $\begin{array}{r}0.003 \\
(0.163)\end{array}$ & & $\begin{array}{l}0.245 \\
(0.210)\end{array}$ \\
\hline $\begin{array}{l}\text { Female respondent } \\
\text { manager }\end{array}$ & & $\begin{array}{r}0.041 \\
(0.061)\end{array}$ & & $\begin{array}{r}0.067 \\
(0.062)\end{array}$ & & $\begin{array}{l}0.110 \\
(0.084)\end{array}$ & & $\begin{array}{r}0.005 \\
(0.063)\end{array}$ & & $\begin{array}{l}0.009 \\
(0.063)\end{array}$ & & $\begin{array}{l}0.157^{* *} \\
(0.064)\end{array}$ & & $\begin{array}{c}0.012 \\
(0.085)\end{array}$ \\
\hline $\mathrm{N}$ & 1588 & 1588 & 1589 & 1589 & 1547 & 1547 & 1589 & 1589 & 1589 & 1589 & 1568 & 1568 & 1588 & 1588 \\
\hline$\chi^{2}$ LR test & $74.35^{* *}$ & $76.58^{* *}$ & $393.83^{* *}$ & $396.10^{* *}$ & $222.42^{* *}$ & $227.78^{* *}$ & $114.00^{* *}$ & $118.23^{* *}$ & $183.30^{* *}$ & $185.01^{* *}$ & $91.83^{* *}$ & $97.89^{* *}$ & $213.08^{* *}$ & $214.46^{* *}$ \\
\hline
\end{tabular}

Notes: All the regressions include as control variables the sets of workplace characteristics and characteristics of the labor force described in Table $2 .{ }^{*}$ Significant at $10 \%$; ${ }^{* *}$ significant at $5 \%$.

female managers significantly affects the two measures of individu alized consideration of employees. Management teams with a higher percentage of females allocate more time in meetings to receiving employee feedback and are more likely to use performance appraisals to improve workers' performance and discuss their career prospects. Remarkably, female human resources managers describe their work places as less prone to employee feedback. This last result may indicate that women managers are also more demanding in this respect.

Summing up, the results offer weak support to the hypothesis that manager employee interactions are more frequent and less formal in workplaces with a higher percentage of female managers. The findings also give weak support to the hypothesis that these workplaces make decisions more democratically. The strongest support from the data analysis is for the hypothesis that workplaces with higher percentages of female managers monitor their employ ees' feedback and development more intensively. In contrast, the evidence clearly does not back the hypothesis that a higher percentage of female managers leads to a more flexible definition of tasks.

\subsection{Robustness assessment: employees' view}

Two potential concerns about the objectivity of respondent managers may cast doubts on the validity of the results from the above analysis. First, their role as human resources managers may create a bias in the perception of management practices that could affect results (Scandura and Williams, 2000). Second, the interview methodology may impose some pressures on respondent managers to provide socially desirable answers instead of sincere ones.

In order to assess the robustness of the results, this subsection exploits the information from the Employee Questionnaire available in the WERS98. The Employee Questionnaire is a written survey about working relationships completed by a random sample of up to 25 workers in each workplace. Some of its questions deal with employ ees' view of management practices. In particular, three groups of questions address the issues to which the last two hypotheses of the previous section refer: (1) whether "their relevant managers have discussed with them any job, promotion, training and pay issues in the last 12 months"; (2) "how often are they asked by their managers about their views on workplace plans, potential changes, staffing issues, pay issues and health and safety conditions"; and (3) "how good are managers at keeping employees informed about proposed changes, obtaining feedback from them and responding to sugges tions". Table 4 summarizes the variables derived from these questions. Unfortunately, no question in the Employee Questionnaire addresses task definition or interpersonal communication (Hypotheses 1 and 2).
The workplace level average of employees' answers to these questions (12 in total) provides a general indicator of their view on each of these issues. The resulting variables share a large part of their variance. The Kaiser Meyer Olkin MSA yields a value of 0.84 , which falls within the "meritorious" category in Kaiser and Rice's (1974) calibration. A factor analysis of these variables is thus suitable. The matrix of varimax rotated factors, resulting from a maximum likelihood factor analysis procedure, is available in Table 5. The figures suggest reducing the information set into three factors, each of them associated with one of the groups of questions described earlier: career mentoring, consultation of decisions, and information and feedback. Workplaces that rate high in a dimension related to one of these factors (e.g., consulting about future plans) also tend to rate high in the rest of dimensions related with that factor (e.g., consulting about pay issues). Therefore, the regression analysis in this case needs to draw on the scores of the resulting factors as dependent variables.

The scores of the three retained factors, computed through Bartlett's (1938) method, provide a measure of employees' assess ment of each aspect for each workplace. Since scores are on a continuous scale, the appropriate method for their analysis is OLS regression.

Table 6 shows the coefficients for the most relevant independent variables of the regression analysis, which includes the same set of controls used to test the hypotheses. Results show that the percentage of female managers has a positive effect on all three factors. Moreover, all coefficients are significant when controlling for the percentage of female non managers. Keeping all other relevant variables constant, a higher percentage of female managers positively affects the degree of consultation of decisions with the non managerial workforce (as reported by employees). This result strengthens the support for Hypothesis 3 from the data from the Management Questionnaire. Also, employees from workplaces with higher percentages of female managers are more likely to report career mentoring from their supervisors and better exchange of ideas. These two results reinforce the strong support for Hypothesis 4 from the Management Question naire data. The lack of accurate questions makes it impossible to use workers' view to check the robustness of the results for the first two hypotheses (task and interpersonal orientation). However, no apparent reason suggests that the results should follow a different pattern for those dimensions.

\section{Discussion}

This study shows that workplace management teams with higher percentages of women tend to apply different people management practices. In particular, they tend to display more individualized consideration of employees. The results also suggest that these 
Table 4

Employees' view of management practices.

\begin{tabular}{|c|c|c|}
\hline Variable description & Mean (standard deviation) & Measurement \\
\hline $\begin{array}{l}\text { Average employee assessment of whether during the last } 12 \text { months they have discussed any of the following } \\
\text { with their supervisor/line manager: }\end{array}$ & & $\mathrm{No}=0 / \mathrm{Yes}=1$ \\
\hline • "How are you getting with your job" & $0.60(0.24)$ & \\
\hline • "Your chances of promotion" & $0.21(0.17)$ & \\
\hline • "Your training needs" & $0.49(0.26)$ & \\
\hline • "Your pay" & $0.29(0.21)$ & \\
\hline Average employees assessment of how often are they asked by managers for their views about the following: & & Discrete scale 1 to 4 : \\
\hline - Future plans for the workplace & $2.37(0.49)$ & $\begin{array}{l}\text { 1: Never } \\
\text { 2: Hardly ever }\end{array}$ \\
\hline - Staffing issues, including redundancy & $1.96(0.40)$ & $\begin{array}{l}\text { 3: Sometimes } \\
\text { 4: Frequently }\end{array}$ \\
\hline - Changes in working practices & $2.58(0.42)$ & \\
\hline • Pay issues & $1.85(0.37)$ & \\
\hline - Health and safety & $2.64(0.50)$ & \\
\hline Employees' assessment of how good managers are at the following: & & Discrete scale 1 to 5 : \\
\hline - Keeping everyone up to date about proposed changes & $3.15(0.56)$ & $\begin{array}{l}\text { 1: Very poor } \\
\text { 2: Poor }\end{array}$ \\
\hline - Providing everyone with the chance to comment on proposed changes & $2.89(0.56)$ & $\begin{array}{l}\text { 3: Neither good nor poor } \\
\text { 4: Good }\end{array}$ \\
\hline - Responding to suggestions from employees & $2.94(0.53)$ & 5: Very good \\
\hline
\end{tabular}

management teams tend to establish more interpersonal channels of communication with employees and promote their participation in decision making, although the evidence with respect to the latter two practices is less conclusive. In other words, as the proportion of women in the management team increases, the practices that are more consistent with their leadership style become more widespread.

In terms of the theoretical framework of this paper, the results support the idea that the influence of women in the overall selection of workplace management practices increases with their relative presence in the management team (Kanter, 1977). Alternatively, these findings could result from women leaders independently applying their preferred styles in a context of low managerial interdependence. If workplace level management practices simply reflect the sum of managers' individual behaviors, an increase in the percentage of female managers will have a proportional impact.

The evidence from the present study alone is not enough to ascertain which of these two explanations is more accurate. However, a comparison with results from the literature on individual manage rial behavior is useful to address this point. Gender differences in leadership styles tend to decrease substantially when researchers compare managers from the same organization (Korac Kakabadse et al., 1998). Pressures exist within organizations towards the homo genization of these leadership styles (House and Aditya, 1997). Therefore, it is unlikely that the different practices observed in work places with higher percentages of female managers result from independent individual decisions. Instead, the findings of this research suggest that the concept of good management workplace practices becomes more consistent with women's leadership styles as the percentage of female managers increases.

\subsection{Contributions of the study}

This paper extends the existing literature on gender differences in leadership styles by incorporating the group composition perspective and analyzing its consequences for workplace level management practices. The existence of gender differences in leadership styles is a controversial issue that attracts the attention of many organization scholars. A number of them, like Loden (1985) and Rosener (1990), propose that women's highly interactive leadership style is better suited than the masculine command and control style to today's less hierarchical and more flexible organizations. In this line, Werhane

Table 5

Results from maximum likelihood factor analysis of employees' view of working relationships (3 factors retained).

\begin{tabular}{|c|c|c|c|c|}
\hline Variable (workplace averages) & Factor 1: information and feedback & Factor 2: career mentoring & Factor 3: consultation of decisions & Uniqueness \\
\hline Job mentoring & 0.083 & 0.842 & 0.009 & 0.242 \\
\hline Promotion mentoring & 0.086 & 0.655 & 0.036 & 0.572 \\
\hline Training mentoring & 0.038 & 0.816 & 0.028 & 0.294 \\
\hline Pay mentoring & 0.134 & 0.247 & 0.088 & 0.924 \\
\hline Consultation of future plans & 0.173 & 0.048 & 0.741 & 0.228 \\
\hline Consultation of staffing issues & 0.048 & 0.006 & 0.818 & 0.381 \\
\hline Consultation of working practices & 0.150 & 0.070 & 0.739 & 0.240 \\
\hline Consultation of pay issues & 0.015 & 0.079 & 0.516 & 0.773 \\
\hline Consultation of health and safety & 0.243 & 0.018 & 0.342 & 0.732 \\
\hline Keep up to date about changes & 0.938 & 0.053 & 0.042 & 0.140 \\
\hline Provide chances to comment & 0.905 & 0.004 & 0.093 & 0.070 \\
\hline Respond to suggestions & 0.845 & 0.010 & 0.030 & 0.251 \\
\hline
\end{tabular}


Women in management and people-management practices: employees' view. OLS coefficients with standard errors in parentheses.

\begin{tabular}{|c|c|c|c|c|c|c|}
\hline & \multicolumn{2}{|c|}{$\underline{\text { Information and feedback }}$} & \multicolumn{2}{|c|}{ Career mentoring } & \multicolumn{2}{|c|}{ Consultation of decisions } \\
\hline & $(1)$ & $(2)$ & (3) & $(4)$ & $(5)$ & $(6)$ \\
\hline $\begin{array}{l}\text { Percentage of female managers } \\
\text { Percentage of female non-managers }\end{array}$ & $0.550^{* *}(0.095)$ & $\begin{array}{l}0.349^{* *}(0.107) \\
0.846^{* *}(0.135)\end{array}$ & $0.138(0.091)$ & $\begin{array}{l}0.210^{* *}(0.104) \\
0.397^{* *}(0.131)\end{array}$ & $0.211^{*}(0.109)$ & $\begin{array}{l}0.315^{* *}(0.123) \\
0.322^{* *}(0.156)\end{array}$ \\
\hline $\mathrm{N}$ & 1589 & 1589 & 1589 & 1589 & 1589 & 1589 \\
\hline $\mathrm{R}^{2}$ & 0.199 & 0.233 & 0.381 & 0.386 & 0.126 & 0.129 \\
\hline
\end{tabular}

Notes: All the regressions include as control variables the sets of workplace characteristics and characteristics of the labor force described in Table $2 .{ }^{*}$ Significant at $10 \%$; ${ }^{* *}$ significant at $5 \%$.

(2007) suggests that women's more collaborative behavior is advantageous in a globalized world.

Although empirical research by social scientists finds more similarities than disparities in the leadership styles of male and female managers (Powell et al., 2002), meta analytical reviews report significant differences in the direction that gender roles predict (Eagly and Johnson, 1990; Eagly and Johannesen Schmidt, 2001). In this context, this study suggests that the contribution of female managers to changes in managerial behavior can also take the form of collective influence on the practices adopted by management teams.

An illustrative case is the more interpersonal orientation expected from female managers. The meta analytical findings of Eagly and Johnson (1990) reveal gender differences in interpersonal style in laboratory experiments and assessment studies but not in the case of real managers. The authors relate this finding to the strong masculinity of the good leader concept that both men and women managers try to fit. Nevertheless, the results of this paper suggest that as the percentage of female managers grows, workplace manage ment employee interactions become more interpersonal. Scholars typically view the existence of tight organizational roles as a restriction that prevents women managers from applying their preferred leadership styles (Terborg, 1977). These organizational roles, however, can be flexible enough to change with variations in the characteristics of their organizations. In particular, workplaces with higher percentages of women in managerial ranks experience more female influence in the definition of good management practices.

Whether women managers make more or less effective leaders than their male counterparts is also a controversial issue (Eagly et al., 1995). Although this specific question is out of the scope of this study, the evidence suggests that women managers' contribution to organizational performance does not lie exclusively in differences in individual effectiveness. Instead, their support for the implementation of some specific people management practices in the workplace is a potentially important source of added value that merits further research.

Some empirical studies provide evidence on the link between employee participation in decision making and superior organiza tional performance (Fernie and Metcalf, 1995; Capelli and Neumark, 2001). Thus, as long as workplace management teams with many women promote employee participation, they should obtain superior performance. Research on the elements moderating the relationship between gender diversity of management ranks and firm perfor mance yields mixed results thus far (Dalton et al., 1998; Dwyer et al., 2003; Krishnan and Park, 2005). The findings of this paper suggest that future investigations on the effect this type of diversity will be more fruitful if they focus explicitly on the kind of people management practices in place.

Finally, the link between the presence of women in management and workplace level practices is relevant for firms' hiring policies and promotion decisions. Companies that try to set up internal labor markets, for example, may have a special interest in keeping a high percentage of female managers. Since these organizations fill managerial positions by promoting lower level workers (Doeringer and Piore, 1971), they care more about mentoring employees and their involvement in decision making. As long as management teams with a higher presence of women are more likely to implement such practices, attracting and retaining female managers is particularly important for these firms.

\section{Acknowledgments}

The author thanks Manuel F. Bagüés, Marco Giarratana, Maia Güell, Peter Mueser, Neus Palomeras and seminar participants at Universi dad Carlos III and IZA for their useful comments on an earlier draft. The author acknowledges the Department of Trade and Industry, the Economic and Social Research Council, the Advisory, Conciliation and Arbitration Service and the Policy Studies Institute as the originators of the 1998 Workplace Employee Relations Survey data, and the Data Archive at the University of Essex as the distributor of the data. None of these organizations bears any responsibility for the author's analysis and interpretations of the data.

\section{References}

Airey C, Hales J, Hamilton R, Korovessis C, McKernan A. The Workplace Employee Relations Survey (WERS) 1997-8: technical report. London: NIESR, WERS98 Data Dissemination Service; 1999.

Aguinis H, Werner S, Abbott JL, Angert C, Park JH, Kohlhausen D. Customer-centric science: reporting research results with rigor, relevance, and practical impact in mind. Organizational Research Methods 2010;13(3):515-39.

Bales RF. Interaction process analysis: a method for the study of small-groups. Cambridge, Massachusetts: Addison-Wesley; 1950.

Bartlett MS. Methods of estimating mental factors. Nature 1938;141:609-11.

Bartlett MS. Tests of significance in factor analysis. Br J Psychol 1950;3(2):77-85.

Bass BM, Riggio EG. Transformational leadership. 2nd ed. Mahwah, NJ: Lawrence Erlbaum Associates; 2006

Berger J, Fisek MH, Norman RZ, Zelditch Jr M. Status characteristics and social interaction: an expectation states approach. New York: Elsevier; 1977.

Blau P. A macrosociological theory of social structure. Am J Sociol 1977;83(1):26-54.

Burns JM. Leadership. New York: Harper \& Row; 1978.

Butterfield DA Grinnell JP. Re-viewing gender, leadership and management behaviour: do three decades of research tell us anything? In: Powell GN, editor. Gender and Work. Newbury Park: Sage; 1999.

Capelli P, Neumark D. Do "high performance" work practices improve establishment level outcomes? Ind Labor Relat Rev 2001:54:737-75.

Carli LL. Gender and social influence. J Soc Issues 2001;57(4):725-41.

Carless SA. Differences in transformational leadership: an examination of superior, leader, and subordinate perspectives. Sex Roles 1998;39:887-902.

Catalyst. Catalyst census of women corporate officers and top earners of the Fortune 500. New York: Catalyst Inc; 2005

Dalton DR, Daily CM, Ellstrand AE, Johnson JL. Meta-analytic reviews of board composition, leadership structure and financial performance. Strateg Manage J 1998;19:269-90.

Department of Trade and Industry. Workplace Employee Relations Survey: CrossSection, 1998 [computer file]. 4th ed. Colchester: The Data Archive [distributor], 22 December 1999. SN: 3955.

Doeringer PB, Piore MJ. Internal labour markets and manpower analysis. Heath, Lexington: Lexington Books; 1971.

Dwyer S, Richard OC, Chadwick K. Diversity in management and firm performance: the influence of growth orientation and organizational culture. J Bus Res 2003;56: 1009-19.

Eagly AH, Johannesen-Schmidt MC. The leadership styles of women and men. J Soc Issues 2001;57:781-97.

Eagly AH, Johnson BT. Gender and leadership style: a meta-analysis. Psychol Bull 1990;108:233-56.

Eagly AH, Karau SJ, Makhijani MG. Gender and the effectiveness of leaders: a metaanalysis. Psychol Bull 1995;117:125-45. 
Fernie S, Metcalf D. Participation, contingent pay, representation and workplace performance: evidence from Great Britain. Br J Ind Relat 1995;33(3):379-415.

House RJ, Aditya RN. The social science study of leadership: quo vadis? J Manage $1997 ; 23(3): 409-74$.

Izraeli DN. Sex effects or structural effects? An empirical test of Kanter's theory of proportions. Soc Forces 1983;62:153-65.

Kaiser HF, Rice J. Little Jiffy, Mark IV. Educ Psychol Meas 1974;34(1):111-7.

Kanter RM. Effects of proportions on group life: skewed sex ratios and responses to token women. Am J Sociol 1977;82(5):965-90.

Kerfoot D, Knights D. Management, masculinity and manipulation: from paternalism to corporate strategy in financial services in Britain. J Manage Stud 1993;30(4): 669-87.

Korac-Kakabadse A, Korac-Kakabadse N, Myers A. Demographics and leadership philosophy: exploring gender differences. J Manage Dev 1998;17(5):351-88.

Krishnan H, Park D. A few good women-on top management. J Bus Res 2005;58: $1712-20$.

Knapp TR, Swoyer VH. Some empirical results concerning the power of Bartlett's test of significance of a correlation matrix. Am Educ Res J 1967;4(1):13-7.

Loden M. Feminine leadership, or how to succeed in business without being one of the boys. New York: Times Books; 1985.

Maher KJ. Gender related stereotypes of transformational and transactional leadership. Sex Roles 1997;37(3):209-25.

Michie J, Sheehan M. HRM practices, R\&D expenditure and innovative investment: evidence from the UK's 1990 Workplace Industrial Relations Survey (WIRS). Ind Corp Change 1999;8(2):211-34.
Milgrom J, Roberts P. Complementarities and fit: strategy, structure, and organizationa change in manufacturing. J Acc Econ 1995;19:179-208.

Powell GN, Butterfield DA, Parent JD. Gender and management stereotypes: have the times changed? J Manage 2002;28:177-93.

Powell GN, Graves LM. Women and men in management. 3rd Edition. Thousand Oaks: Sage; 2003.

Ridgeway CL, Berger J. Expectations, legitimation, and dominance behaviour in task groups. Am Sociol Rev 1986;51(5):603-17.

Rosener JB. Ways women lead. Harv Bus Rev 1990;68(6):119-25.

Scandura TA, Williams EA. Research methodology in management: current practices, trends, and implications for further research. Acad Manage J 2000;43(6):1248-64.

Stewart DW. The application and misapplication of factor analysis in marketing research. J Mark Res 1981;18(1):51-62.

Terborg JR. Women in management: a research review. J Appl Psychol 1977;62(6): 647-64.

Thomas S. The impact of women on state legislative policies. J Polit 1991;53(4):958-76 United Kingdom Statistics Authority, 2007. Retrieved from www.statistics.gov.uk.

United States Bureau of Labor Statistics, 2007. Retrieved from www.bls.gov.

Vroom VH, Yetton PW. Leadership and decision-making. Pittsburgh: University of Pittsburgh Press; 1973.

Werhane PH. Women leaders in a globalized world. J Bus Ethics 2007;74(4):425-35.

Wooldridge J. Econometric analysis of cross section and panel data. Cambridge MA: MIT Press; 2002. 